\title{
KARY I ŚRODKI KARNE W POLSKIM KODEKSIE KARNYM ORAZ EKWIWALENTY ICH NAZW W JEZZYKU NIEMIECKIM
}

\author{
Katarzyna SIEWERT-KOWALKOWSKA, dr \\ Uniwersytet Kazimierza Wielkiego w Bydgoszczy \\ Instytut Neofilologii i Lingwistyki Stosowanej \\ ul. Grabowa 2, 85-601 Bydgoszcz \\ e-mail: katarzynasiewert@wp.pl
}

\begin{abstract}
Abstrakt: Prawo karne w odróżnieniu od innych gałęzi prawa nie reguluje określonej sfery życia społecznego, jak np. prawo rodzinne czy prawo pracy, lecz chroni dobra i wartości uznawane przez dane społeczeństwo za najważniejsze. Sprawcy naruszającemu normy prawa karnego grożą najdotkliwsze sankcje, a mianowicie utrata lub ograniczenie dóbr wysoko cenionych przez każdego człowieka, jakimi są wolność, wartości majątkowe czy dobre imię. Przedmiotem artykułu są wybrane pojęcia polskiego prawa karnego w kontekście przekładu tekstów prawnych na język niemiecki. Na wstępie zostanie przedstawiony system kar i środków karnych przewidzianych w polskim kodeksie karnym w porównaniu z systemem obowiązującym w Niemczech. $\mathrm{Na}$ tej podstawie zostanie przeprowadzona analiza ekwiwalentów zaproponowanych w wybranym słowniku prawniczym polsko-niemieckim oraz rozwiązań translatorskich zastosowanych w przekładzie polskiego kodeksu karnego na język niemiecki.
\end{abstract}

\section{PENALTIES AND PENAL MEANS IN THE POLISH PENAL CODE AND EQUIVALENTS OF THEIR NAMES IN GERMAN}

Abstract: The penal law, in contrast to other branches of law, such as the labour law or the family law, doesn't regulate any sphere of social life, but protects goods and values regarded as most important by a given society. The perpetrator who violates regulations of the penal law is liable to the most severe sanctions, namely, loss or limitation of the most important human values like freedom, property or good name. The present article addresses selected terms of the Polish penal law with reference to their equivalents in the German system. The article begins with the presentation of the system of penalties and penal means in the Polish penal code and its comparison with the system being legally binding in Germany. This is followed by an analysis of the equivalents from a selected Polish-German dictionary and of translation solutions in the German translation of the Polish penal code. 


\section{Wstęp}

Prawo karne stanowi jedną $\mathrm{z}$ wielu gałęzi prawa, która w systemie prawa każdego państwa pełni wyjątkową rolę. Nie reguluje ono bowiem określonej sfery stosunków społecznych, jak np. prawo rodzinne czy prawo pracy, lecz ingeruje w różne dziedziny życia, chroniąc określony system wartości zagrożony występowaniem zjawisk patologicznych, które w różnych okresach historycznych mogą mieć różne nasilenie (por. Bojarski 2008, 17; Daniluk 2011, 338). Ich wzrost obserwuje się zwłaszcza dziś, $\mathrm{w}$ dobie postępującego procesu globalizacji, przejawiającego się w intensyfikacji przepływu kapitału, ludzi i technologii i prowadzącego między innymi do integrowania się państw, społeczeństw i kultur. W 2001 r. Ryszard Kapuściński $(2008,189)$ zwrócił uwagę, iż obok tak rozumianej globalizacji, ocenianej najczęściej pozytywnie, istnieje jeszcze globalizacja negatywna, „globalizacja świata podziemnego, przestępczego, mafii, narkotyków, masowego handlu bronią, prania brudnych pieniędzy, unikania płacenia podatków, oszustw finansowych" oraz handlu ludźmi, korupcji i terroryzmu.

Rozwojowi przestępczości, zwłaszcza tej zorganizowanej, sprzyja przede wszystkim łatwość nawiązywania kontaktów dzięki swobodnemu przepływowi ludzi na skutek otwartych granic oraz dzięki gwałtownemu rozwojowi środków komunikacji elektronicznej. Działalność przestępcza ma bardzo często charakter międzynarodowy (por. Gabriel-Węglowski 2011, 73-74), także w Polsce. Na przykład w 2003 r. działalność przestępczą w Polsce prowadziło 250 grup przestępczych, wśród których były też grupy o składzie międzynarodowym. Uczestniczyły w nich 522 osoby pochodzące z 19 państw (por. Hołyst 2005, 804). Wobec tak poważnego zagrożenia dla porządku publicznego Polska, która dnia 1 maja 2004 r. stała się państwem członkowskim Unii Europejskiej, włączyła się w działania mające na celu walkę z przestęppczością zorganizowaną i transgraniczną na szczeblu europejskim. Działania te opierają się w głównej mierze na skutecznej współpracy między organami państw członkowskich, a zwłaszcza organami ścigania, której wyrazem jest między innymi wzajemne uznawanie wyroków i innych orzeczeń organów sądowych (por. Walka z przestęppczością zorganizowaną). Podstawowym aktem prawnym wyznaczającym ramy wzajemnej współpracy jest Europejska konwencja o pomocy prawnej w sprawach karnych z dnia 20 kwietnia 1959 r. Na mocy art. 16 ust. 2 tej konwencji wiele państw złożyło oświadczenia o wymaganiu tłumaczenia wniosków o udzielenie pomocy prawnej w sprawach karnych i załączonych dokumentów. Wśród nich znalazły się także państwa, w których językiem urzędowym jest język niemiecki, a więc Niemcy, Austria, Szwajcaria, Lichtenstein, Luksemburg i Belgia (por. Ciszewski 2008, 811-812).

Aby móc sprostać wymogom zapewnienia odpowiedniej jakości tłumaczenia i przyczynić się tym samym do efektywnej współpracy sądowej na płaszczyźnie międzynarodowej, tłumacz musi posiadać określony poziom wiedzy specjalistycznej, kulturowej, językowej oraz kompetencji translatorskiej (por. Jopek-Bosiacka 2006, 3031). Jednym z podstawowych warunków wykonania dobrej jakości tłumaczenia jest, jak podkreśla się w literaturze przedmiotu, wybór właściwego ekwiwalentu terminowogicznego w języku docelowym. Tę kluczową fazę tłumaczenia poprzedza wnikliwa analiza treści pojęć używanych przez ustawodawcę (Groot 1999, 11, Jopek-Bosiacka 
2006, 30, Weisflog 1996, 117). Celem niniejszego artykułu jest zbadanie treści pojęć poszczególnych kar i środków karnych, analiza zaproponowanych ekwiwalentów słownikowych i przekładowych oraz próba ich oceny z punktu widzenia tłumaczenia tekstów prawnych na język niemiecki w określonej sytuacji komunikacyjnej.

\section{System sankcji karnych w polskim kodeksie karnym}

Jak podkreśla Andrzej Marek (2005, 5), prawo karne spełnia szczególną rolę wśród gałęzi prawa, ponieważ chroni ono państwo i stosunki społeczno-ekonomiczne oraz prawa i wolności człowieka przed najpoważniejszymi zamachami na te dobra, a mianowicie przed przestępstwami. Ochronę dóbr zapewnia się, stosując wobec sprawców przestępstw represje $\mathrm{w}$ postaci kar i innych środków przewidzianych $\mathrm{w}$ przepisach prawa karnego (por. Marek 2005, 5; Bojarski 2008, 31).

Tradycyjną formą reakcji na popełnienie przestępstwa jest kara, nazywana karą kryminalną, czyli bardzo ostry środek przymusu państwowego służący do zwalczania przestępstw (por. Bojarski 2008, 24, 237). Jest to instrument specyficzny, ponieważ od środków prawnych funkcjonujących w innych działach prawa, takich jak prawo cywilne czy prawo administracyjne, różni się przede wszystkim stopniem dolegliwości. Kara kryminalna dotyka bowiem podstawowych wartości, jakimi są m. in. wolność i mienie sprawcy przestępstwa (por. Hołyst 2005, 301). Poza tym kara ma charakter osobisty, ponieważ kary nie można odbywać za skazanego (por. Bojarski 2008, 237). Co ciekawe, odmienność tej represji karnej znajduje także swój wyraz w języku, ponieważ sprawcę naruszającego normy prawa karnego „skazuje się”, a karę za przestępstwo sąd „orzeka”, a nie „zasądza”, co ma miejsce w przypadku odszkodowania w procesie cywilnym (por. Bojarski 2008, 238).

Katalog kar, które ma do dyspozycji sąd, zawarty jest w art. 32 ustawy z dnia 6 czerwca 1997 r. - Kodeks karny, i obejmuje kolejno:

1) grzywnę,

2) ograniczenie wolności,

3) pozbawienie wolności,

4) 25 lat pozbawienia wolności oraz

5) dożywotnie pozbawienie wolności.

Należy dodać, że dla żołnierzy kodeks karny przewiduje jeszcze karę aresztu wojskowego w wymiarze od jednego miesiąca do 2 lat (art. 322 k.k.).

Wobec sprawców przestępstw oprócz ww. kar sąd może również orzec tzw. środki karne, które wymierzane są łącznie z karą jako jej uzupełnienie lub też które mogą być orzekane zamiast kary (por. Budyn-Kulik et al. 2011, 20; Hołyst 2005: 1019). Artykuł 39 k.k. zawiera następujący katalog środków karnych: 
1) pozbawienie praw publicznych,

2) zakaz zajmowania określonego stanowiska, wykonywania określonego zawodu lub prowadzenia określonej działalności gospodarczej,

3) zakaz prowadzenia działalności związanej z wychowaniem, leczeniem, edukacją małoletnich lub z opieką nad nimi,

4) obowiązek powstrzymania się od przebywania w określonych środowiskach lub miejscach, zakaz kontaktowania się z określonymi osobami, zakaz zbliżania się do określonych osób lub zakaz opuszczania określonego miejsca pobytu bez zgody sądu,

5) zakaz wstępu na imprezę masową,

6) zakaz wstępu do ośrodków gier i uczestnictwa w grach hazardowych,

7) nakaz opuszczenia lokalu zajmowanego wspólnie z pokrzywdzonym,

8) zakaz prowadzenia pojazdów,

9) przepadek,

10) obowiązek naprawienia szkody lub zadośćuczynienia za doznaną krzywdę,

11) nawiązka,

12) Świadczenie pieniężne,

13) podanie wyroku do publicznej wiadomości.

14)

Obok wymienionych tutaj istnieją dodatkowo środki karne orzekane wobec żołnierzy, którymi są wydalenie z zawodowej służby wojskowej i degradacja (art. 324 k.k.).

Wszystkie powyższe środki karne stanowią treść pojęcia środki karne w węższym znaczeniu. W doktrynie prawa karnego pojęcie to występuje także w szerszym znaczeniu, a mianowicie jako każda forma reakcji na czyn zabroniony, i jest ono synonimem kary. W tym znaczeniu pojęcie to obejmuje wszystkie kary, środki karne w wąskim znaczeniu, środki wychowawcze i poprawcze stosowane wobec nieletnich oraz środki probacyjne, czyli środki związane $\mathrm{z}$ poddaniem sprawcy próbie (por. Bojarski 2008, 25, 249; Cieślak 2010, 177; Pawela 2007, 223).

Odnośnie do przytoczonych powyżej znaczeń pojęcia środki karne w literaturze przedmiotu można znaleźć uwagi krytyczne co do podziału reakcji penalnych na kary i środki karne, jaki przewiduje obowiązująca ustawa Kodeks karny z 1997 r. Podkreśla się, że podział taki jest wadliwy zarówno ze względów merytorycznych, jak i językowych. Zmianę dotychczasowych nazw kary zasadnicze oraz kary dodatkowe występujących w kodeksie karnym z 1969 r. uzasadniano tym, iż środki karne mogą być orzekane bez zastosowania kary, a niektóre z nich tracą wręcz charakter kary, jak np. naprawienie szkody. Z tego względu uważano, iż nowa nazwa nie będzie podkreślać ich karnego charakteru. Jednak $\mathrm{z}$ merytorycznego punktu widzenia funkcja większości $\mathrm{z}$ nich nadal jest represyjna. Błąd językowy polega natomiast na tym, że nie powinno się dokonywać podziału dychotomicznego pojęć o takim samym znaczeniu i pojęciom o utrwalonej tradycji nadawać nowego, sztucznego znaczenia. Bardziej uzasadnionym byłby podział na kary zasadnicze i inne kary bądź inne środki karne (por. Bojarski 2008, 249). 


\section{System sankcji karnych w niemieckim kodeksie karnym}

W Niemczech odpowiednikiem polskiej ustawy Kodeks karny z 1997 r. jest ustawa Strafgesetzbuch (StGB) z 1871 r. w brzmieniu obowiązującym od dnia 13 listopada 1998 r. W odróżnieniu od polskiego niemiecki kodeks karny przewiduje trójpodział sankcji karnych będących reakcją na przestępstwo, a mianowicie na kary zasadnicze (Hauptstrafen; dosł. kary główne), kary dodatkowe (Nebenstrafen) i środki karne (Nebenfolgen, dosł. dodatkowe skutki wyroku) (por. Creifelds 2014, 1206; Steinborn 2011, 690).

Katalog kar zasadniczych, które jako takie mogą być wymierzone samoistnie, obejmuje dwie kary:

1) karę pozbawienia wolności (Freiheitsstrafe), która może być terminowa (zeitige Freiheitsstrafe) od 1 miesiąca do 15 lat lub dożywotnia (lebenslange Freiheitsstrafe) (§ $38 \mathrm{StGB})$, oraz

2) grzywnę (Geldstrafe) (§ $40 \mathrm{StGB})$.

Warto zauważyć, iż $§ 43 a$ StGB jako karę zasadniczą przewiduje dodatkowo karę majątkową (Vermögensstrafe), lecz w obowiązującym stanie prawnym zgodnie z orzeczeniem Trybunału Federalnego nie może być ona orzekana ze względu na niezgodność z konstytucją (por. Creifelds 2014, 1207).

Kary dodatkowe to kary uzupełniające orzekane obok kar zasadniczych. Niemiecki kodeks karny wyraźnie wymienia tylko jedną karę dodatkową, tzn. zakaz prowadzenia pojazdów mechanicznych (Fahrverbot) ( $\$ 44$ StGB). Jednak w praktyce do tego rodzaju kar zalicza się także podanie wyroku skazującego do publicznej wiadomości (Bekanntgabe der Verurteilung) oraz przepadek (Einziehung) (por. Creifelds 2014, 896; Köbler 2007, 288).

Do trzeciej grupy sankcji, czyli do środków karnych, zgodnie z $§ 45$ StGB, należy utrata prawa do pełnienia urzędów publicznych oraz biernego i czynnego prawa wyborczego (Verlust der Amtsfähigkeit, der Wählbarkeit und des Stimmrechts), (por. też Alpmann-Pieper et al. 2010, 838). W niemieckiej literaturze przedmiotu, podobnie jak w polskiej, podkreśla się, że środki karne nie mają charakteru kary, ponieważ sąd może je wymierzyć tylko łącznie z karą główną (por. Köbler 2007, 288).

\section{Problem tłumaczenia nazw kar i środków karnych na język niemiecki}

Na podstawie przedstawionego powyżej opisu sankcji karnych przewidzianych zarówno w polskim, jak i w niemieckim kodeksie można już na wstępie stwierdzić, że katalog polskich kar i środków karnych jest obszerniejszy i że niektóre z nich nie są znane niemieckiemu prawu karnemu. Dlatego też ich tłumaczenie na język niemiecki może stanowić problem translacyjny. 
W dalszej części artykułu zostaną przeanalizowane propozycje tłumaczenia nazw kar i środków karnych na język niemiecki zawarte w najnowszym dwujęzycznym słowniku specjalistycznym „Słownik języka prawnego i ekonomicznego" autorstwa Aliny i Agnieszki Kilian z 2014 roku. Propozycje te zostaną następnie skonfrontowane z ekwiwalentami przekładowymi występującymi w tłumaczeniu polskiego kodeksu karnego na język niemiecki, który ukazał się w 2012 r. nakładem Wydawnictwa C.H. Beck. Na tej podstawie zostanie następnie podjęta próba oceny obu rodzaju rozwiązań w kontekście przyjętego modelu sytuacji komunikacyjnej.

Przed przystąpieniem do analizy należy przypomnieć obowiązującą w teorii przekładu zasadę, że ,gdy tłumaczymy, tłumaczymy dla kogoś, w konkretnym celu i w konkretnej sytuacji komunikacyjnej" (Dybiec-Gajer 2013, 107) i jednocześnie nakreślić istotne parametry sytuacji komunikacyjnej, w jakiej funkcjonują translaty tekstów tłumaczonych na potrzeby pomocy prawnej w sprawach karnych. Pomocny okazuje się tutaj model pragmatycznego thumaczenia terminów prawnych opracowany przez Danutę Kierzkowską (2002, 72-86). Autorka podkreśla, że model skupia się przede wszystkim na dwóch rodzajach ograniczeń wyznaczających kierunek działania tłumacza tekstów prawniczych, tj. na ograniczeniach wynikających z typu odbiorcy i rodzajów uzusu terminologicznego. Restrykcje te zostały określone mianem imperatywu odbiorcy i imperatywu uzusu. Bowiem dopiero po określeniu imperatywu odbiorcy i imperatywu uzusu tłumacz może dokonać wyboru rodzaju strategii thumaczenia poprzez wybór odpowiedniego typu ekwiwalencji tekstu docelowego w stosunku do tekstu wyjściowego (por. Kierzkowska 2002, 87).

W analizowanej w niniejszym artykule sytuacji należy przyjąć, że odbiorcą przekładu, którym są sądy i prokuratury prowadzące postępowania w sprawach z elementem obcym, będzie odbiorca daleki, ponieważ nie musi się on zapoznawać $\mathrm{z}$ obcym systemem prawa (w tym przypadku z polskim) i preferuje terminologię znaną $\mathrm{mu} \mathrm{z}$ rodzimego systemu prawa, choćby była ona nawet nieprecyzyjna (por. Kierzkowska 2010, 266-267). Określenie typu odbiorcy zawiera już wskazówkę dotyczącą uzusu terminologicznego, którym będzie uzus narodowy, czyli stosowanie narodowej terminologii preskryptywnej, tj. występującej w aktach danego państwa publikowanych $\mathrm{w}$ dziennikach promulgacyjnych (w tym przypadku w polskich aktach prawnych) (por. Kierzkowska 2002, 92).

Po ustaleniu typu odbiorcy i rodzaju uzusu można przystąpić do wyboru strategii tłumaczenia. Zgodnie $\mathrm{z}$ modelem Danuty Kierzkowskiej w thumaczeniu dokumentów funkcjonujących $\mathrm{w}$ obrocie prawnym $\mathrm{z}$ zagranicą $\mathrm{w}$ sprawach karnych dla odbiorcy dalekiego można przyjąć ekwiwalencję tekstowo-normatywną oraz ekwiwalencję konotacyjną. Ekwiwalencja tekstowo-normatywna to stosowanie norm językowych i tekstowych właściwych dla języka prawnego, ustalonych przez konwencję i tradycję językową. Ten rodzaj ekwiwalencji obowiązuje dla wszystkich rodzajów tekstów (por. Kierzkowska 2002, 96-97).

Natomiast ekwiwalencja konotacyjna polega na odnoszeniu terminów i oznaczanych przez nie pojęć tekstu wyjściowego do skojarzeń związanych z pojęciami 
kultury prawnej języka docelowego, które są znane odbiorcy tłumaczenia (por. Kierzkowska 2002, 95). Stwierdzenie to nabiera szczególnego znaczenia dla języka niemieckiego, który jest językiem pluricentrycznym i występuje różnych odmianach (por. Kubacki 2014, 165). Jest to o tyle ważne, że tłumacz, dokonując przekładu tekstów prawnych, musi świadomie wybrać porządek prawny, którego terminologię będzie konsekwentnie stosował w translacie, a więc terminologię niemiecko-niemiecką, austriacko-niemiecką, helweto-niemiecką, liechtensteińsko-niemiecką, belgijskoniemiecką, czy też terminologię włosko-niemiecką, gdyż każde państwo posiada własny system prawny i tym samym własną terminologię (por. Groot 1999, 12, 18; Kubacki 2014, 172). W opisywanej w niniejszym artykule sytuacji komunikacyjnej będzie to język niemiecki systemu prawnego Republiki Federalnej Niemiec.

Z uwagi na obszerny katalog kar i środków karnych w polskim prawie karnym można przypuszczać, że tłumacz będzie musiał zmierzyć się z problemem terminów bezekwiwalentnych. Termin bezekwiwalentny to „termin, który nazywa byt istniejący w rzeczywistości prawnej języka źródłowego, ale nie istniejący w rzeczywistości prawnej języka docelowego" (Matulewska 2005, 65). W takim przypadku będzie on zmuszony podjąć decyzję co do sposobu utworzenia nowego terminu, czyli wybrać jedną z wielu technik tworzenia terminów, spośród których Aleksandra Matulewska (2005, 65) wymienia m. in. (por. też Kierzkowska 2002, 118-123):

1. wyrażenie egzotyczne, czyli rodzaj zapożyczenia zachowującego pisownię terminu języka docelowego (common law),

2. zapożyczenie $\mathrm{z}$ dostosowaniem pisowni do zasad rządzących językiem docelowym (Eksczekier),

3. kalka językowa (sędzia-komisarz-judge-commissioner),

4. ekwiwalent funkcjonalny, czyli zastosowanie najbliższego ekwiwalentu znanego w rzeczywistości prawnej języka docelowego (spółka komandytowa - limited partnership),

5. neologizm, czyli utworzenie zupełnie nowego terminu nieznanego w kulturze języka docelowego (prokurent-commercial representative),

6. ekwiwalent opisowy w postaci definicji (equity jako system prawny oparty na zasadach słuszności stosowany w Anglii),

7. dwa terminy na oznaczenie jednego np.: mortgage - hipoteka i zastaw,

8. ekwiwalent zorientowany na język źródłowy modyfikujący termin znany w kulturze języka docelowego (spółka z ograniczonq odpowiedzialnościa - limited liability company),

9. ekwiwalent zawierający w sobie termin języka źródłowego, ale szerszy znaczeniowo (partnership - spółka),

10. ekwiwalent ograniczający (lease-dzierżawa).

Po określeniu istotnych elementów sytuacji komunikacyjnej przyjrzymy się rozwiązaniom translacyjnym dla nazw kar i środków prawnych, proponowanym w polsko-niemieckich słowniku specjalistycznym oraz zastosowanych w przekładzie polskiego kodeksu karnego na język niemiecki. Tabela 1 zawiera ekwiwalenty dla nazw kar zawartych w art. 32 i 322 k.k.). 
Comparative Legilinguistics 21/2015

Tab. 1: Niemieckie ekwiwalenty przekladowe dla polskich nazw kar

\begin{tabular}{|c|c|c|c|}
\hline & Nazwa kary & Kilian/Kilian & Przekład Chudzik et al. \\
\hline 1 & kara grzywny & Geldstrafe & Geldstrafe \\
\hline 2 & $\begin{array}{l}\text { kara } \\
\text { ograniczenia } \\
\text { wolności }\end{array}$ & Freiheitsbeschränkungsstrafe & Freiheitsbeschränkungsstrafe \\
\hline 3 & $\begin{array}{l}\text { kara pozbawienia } \\
\text { wolności }\end{array}$ & Freiheitsstrafe & Freiheitsstrafe \\
\hline 4 & $\begin{array}{l}\text { kara } 25 \text { lat } \\
\text { pozbawienia } \\
\text { wolności }\end{array}$ & Freiheitsstrafe von 25 Jahren & 25 Jahre Freiheitsstrafe \\
\hline 5 & $\begin{array}{l}\text { kara } \\
\text { dożywotniego } \\
\text { pozbawienia } \\
\text { wolności }\end{array}$ & lebenslange Freiheitsstrafe & lebenslange Freiheitsstrafe \\
\hline 6 & $\begin{array}{l}\text { kara aresztu } \\
\text { wojskowego }\end{array}$ & - & $\begin{array}{c}\text { Strafe des militärischen } \\
\text { Arrests }\end{array}$ \\
\hline
\end{tabular}

Dla nazw kar, które mają swoje odpowiedniki w niemieckim kodeksie karnym, tj. grzywna, kara pozbawienia wolności oraz kara dożywotniego pozbawienia wolności zarówno w słowniku, jak i w tłumaczeniu zaproponowano ekwiwalenty funkcjonalne. Istotne jest, aby jednak pamiętać, że zakresy znaczeniowe niemieckich pojęć prawnych oraz polskich pojęć prawnych reprezentowanych w thumaczeniu przez ekwiwalenty funkcjonalne nie zawsze się pokrywają. Taką samą treść mają pojęcia kara dożywotnego pozbawienia wolności i lebenslange Freiheitsstrafe oraz kara pozbawienia wolności i Freiheitsstrafe. W przypadku tego drugiego rodzaju kary jej wymiar w obu systemach prawnych wynosi od 1 miesiąca do 15 lat (art. 37 k.k. oraz $§ 38$ pkt 2 StGB). Pojęcia kary grzywny i Geldstrafe różnią się natomiast granicami orzekania tego rodzaju kary. Zarówno w polskim, jak i w niemieckim systemie prawnym karę grzywny wymierza się w stawkach dziennych, przy czym w polskim kodeksie karnym liczba stawek wynosi od 10 do 540, a jedna stawka może mieć wartość od 10 do 2.000 zł (art. $33 \S 1$ i 3 k.k.), a w niemieckim kodeksie karnym liczba stawek wynosi od 5 do 360, a wartość jednej stawki od 1 do 30.000 euro (§ 40 pkt 1 i 2).

Dla terminów bezekwiwalentnych kara ograniczenia wolności i kara 25 lat pozbawienia wolności zostały utworzone nowe terminy z wykorzystaniem terminów znanych w kulturze niemieckiego języka prawnego. Termin Freiheitsbeschränkungsstrafe, który pojawia się w obu analizowanych publikacjach jako ekwiwalent nazwy kary ograniczenia wolności, powstał $\mathrm{z}$ połączenia dwóch niemieckich terminów prawnych, a mianowicie Freiheitsbeschränkung oraz Strafe. Freiheitsbeschränkung występuje w niemieckim prawie o Policji i oznacza ograniczenie jakiejś osobie możliwości zmiany miejsca pobytu, 
a Strafe podobnie jak w polskim prawie karnym to sankcja prawna przewidziana w ustawie karnej za jej naruszenie (por. Alpmann-Pieper et al. 2010, 470, 1119). Ekwiwalent terminu kara 25 lat pozbawienia wolności został utworzony z wykorzystaniem niemieckiego terminu prawnego Freiheitsstrafe. Można przy tym stwierdzić, że ekwiwalent zaproponowany w słowniku Aliny i Agnieszki Kilian zorientowany jest na język docelowy, a rozwiązanie translacyjne zastosowane w przekładzie polskiego kodeksu karnego ma charakter ekwiwalentu zorientowanego na język źródłowy, ponieważ jego struktura morfologiczna jest odwzorowaniem struktury terminu źródłowego. Z punktu widzenia przyjętych założeń dotyczących parametrów sytuacji komunikacyjnej trafniejszym rozwiązaniem jest odpowiednik słownikowy.

Za termin bezekwiwalentny nie można uznać terminu kara aresztu wojskowego, ponieważ w prawie niemieckim istnieje podobny byt prawny, a mianowicie Strafarrest. Jest to szczególny rodzaj kary przewidziany w $\S \S 10-12$ obowiązującej w Niemczech wojskowej ustawy karnej (Wehrstrafgesetz), który sąd może orzekać tylko $\mathrm{w}$ przypadku przestępstw popełnianych przez żołnierzy (por. Alpmann-Pieper et al. 2010, 1115). Dlatego też $\mathrm{w}$ analizowanej tutaj sytuacji komunikacyjnej można by wykorzystać termin istniejący już w niemieckim porządku prawnym jako ekwiwalent konotacyjny. Słownik Aliny i Agnieszki Kilian z 2014 r. nie notuje niestety tego terminu. Rozwiązanie translacyjne zaproponowane przez autorów przekładu polskiego kodeksu karnego, czyli Strafe des militärischen Arrests, to ekwiwalent zorientowany na język źródłowy. Ten nowo utworzony termin, który stanowi kalkę językową, jest przejrzysty znaczeniowo i z tego względu jest także akceptowalny.

Przeanalizujmy teraz ekwiwalenty niemieckie zaproponowane dla nazw środków karnych, które przedstawia tabela 2.

Tab. 2: Niemieckie ekwiwalenty przekładowe dla polskich nazw środków karnych

\begin{tabular}{|c|l|c|c|}
\hline \multicolumn{1}{|c|}{ Nazwa kary } & Kilian/Kilian & Przeklad Chudzik et al. \\
\hline 1 & środek karny & Strafmaßnahmen & Strafmittel \\
\hline 2 & $\begin{array}{l}\text { pozbawienie praw } \\
\text { publicznych }\end{array}$ & $\begin{array}{c}\text { Aberkennung der } \\
\text { bürgerlichen Ehrenrechte }\end{array}$ & $\begin{array}{c}\text { Aberkennung öffentlicher } \\
\text { Rechte }\end{array}$ \\
\hline 3 & $\begin{array}{l}\text { zakaz zajmowania } \\
\text { określonego stanowiska, } \\
\text { wykonywania określonego } \\
\text { zawodu lub prowadzenia } \\
\text { określonej działalności } \\
\text { gospodarczej }\end{array}$ & $\begin{array}{l}\text { Vestimmter Ämter, } \\
\text { Berufsverbot, } \\
\text { Gewerbeuntersagung }\end{array}$ & $\begin{array}{c}\text { Verbot, einen bestimmten } \\
\text { Posten zu bekleiden, einen } \\
\text { bestimmten Beruf auszuüben } \\
\text { oder eine bestimmte } \\
\text { Wirtschaftliche Tätigkeit zu } \\
\text { betreiben }\end{array}$ \\
\hline 4 & $\begin{array}{l}\text { zakaz prowadzenia } \\
\text { działalności zwiqzanej } z \\
\text { wychowaniem, leczeniem, } \\
\text { edukacja małoletnich lub } z \\
\text { opieka nad nimi }\end{array}$ & - & $\begin{array}{c}\text { Verbot, eine Tätigkeit } \\
\text { auszuüben, die im }\end{array}$ \\
$\begin{array}{l}\text { Zusammenhang mit der } \\
\text { Erziehung, Heilung, Bildung } \\
\text { oder Betreuung } \\
\text { Minderjähriger steht }\end{array}$ \\
\hline
\end{tabular}




\begin{tabular}{|c|c|c|c|}
\hline 5 & $\begin{array}{l}\text { obowiazek powstrzymania } \\
\text { się od przebywania w } \\
\text { określonych środowiskach } \\
\text { lub miejscach, zakaz } \\
\text { kontaktowania się z } \\
\text { określonymi osobami, } \\
\text { zakaz zbliżania się do } \\
\text { określonych osób lub zakaz } \\
\text { opuszczania określonego } \\
\text { miejsca pobytu bez zgody } \\
\text { sqddu }\end{array}$ & $\begin{array}{c}\text { Weisung mit bestimmten } \\
\text { Personenkreisen nicht zu } \\
\text { verkehren }\end{array}$ & $\begin{array}{c}\text { Verpflichtung, sich von } \\
\text { bestimmten Kreisen oder Orten } \\
\text { fernzuhalten, das Verbot zu } \\
\text { bestimmten Personen Kontakt } \\
\text { aufzunehmen oder das Verbot, } \\
\text { einen bestimmten } \\
\text { Aufenthaltsort ohne Erlaubnis } \\
\text { des Gerichts zu verlassen }\end{array}$ \\
\hline 6 & $\begin{array}{l}\text { zakaz wstępu na imprezę } \\
\text { masowa }\end{array}$ & - & $\begin{array}{c}\text { Eintrittsverbot zu einer } \\
\text { Massenveranstaltung }\end{array}$ \\
\hline 7 & $\begin{array}{l}\text { zakaz wstępu do ośrodków } \\
\text { gier i uczestnictwa w grach } \\
\text { hazardowych }\end{array}$ & - & $\begin{array}{c}\text { Eintrittsverbot in Spielhallen } \\
\text { oder das Teilnahmeverbot an } \\
\text { Glücksspielen }\end{array}$ \\
\hline 8 & $\begin{array}{l}\text { nakaz opuszczenia lokalu } \\
\text { zajmowanego wspólnie z } \\
\text { pokrzywdzonym }\end{array}$ & - & - \\
\hline 9 & $\begin{array}{l}\text { zakaz prowadzenia } \\
\text { pojazdów }\end{array}$ & Fahrverbot & Fahrverbot \\
\hline 10 & przepadek & Einziehung, Verfall & Verfall \\
\hline 11 & $\begin{array}{l}\text { obowiazek naprawienia } \\
\text { szkody lub } \\
\text { zadośćuczynienia za } \\
\text { doznana krzywde }\end{array}$ & $\begin{array}{c}\text { Schadensersatzpflicht, } \\
\text { Wiedergutmachungspflicht } \\
\text {, Wiedergutmachung eines } \\
\text { Nichtvermögensschadens }\end{array}$ & $\begin{array}{c}\text { Verpflichtung zur } \\
\text { Schadenswiedergutmachung } \\
\text { oder Genugtuung für das } \\
\text { erfahrene Leid }\end{array}$ \\
\hline 12 & nawiq̨za & Bußzahlung & Geldauflage \\
\hline 13 & świadczenie pieniężne & Geldleistung & Geldleistung \\
\hline 14 & $\begin{array}{l}\text { podanie wyroku do } \\
\text { publicznej wiadomości }\end{array}$ & $\begin{array}{c}\text { öffentliche Bekanntgabe } \\
\text { des Urteils }\end{array}$ & $\begin{array}{c}\text { öffentliche Bekanntgabe des } \\
\text { Urteils }\end{array}$ \\
\hline 15 & $\begin{array}{l}\text { wydalenie z zawodowej } \\
\text { służby wojskowej }\end{array}$ & - & $\begin{array}{c}\text { Entlassung aus dem } \\
\text { Berufsdienst des Militärs }\end{array}$ \\
\hline 16 & degradacja & Degradierung & Degradierung \\
\hline
\end{tabular}

Środki karne to nowy termin, który został wprowadzony w Kodeksie karnym z 1997 r. i który, jak już wspomniano, budzi pewne kontrowersje w literaturze przedmiotu. Choć niektórzy prawnicy podkreślają, że funkcja środków karnych nie różni się praktycznie od funkcji dawnych kar dodatkowych, to jednak thumacz nie może ingerować w ustaloną przez ustawodawcę terminologię i thumaczyć terminu środki karne jako Nebenstrafen, utożsamiając $\mathrm{w}$ ten sposób polskie pojęcie prawne z niemieckim. $\mathrm{Z}$ tego też względu zaproponowany ekwiwalent słownikowy, jak i przekładowy, które są kalką językową, należy uznać za słuszne rozwiązanie. 
Większość spośród wymienionych w powyższej tabeli środków karnych przewidzianych w polskim kodeksie karnym to formy reakcji na czyn zabroniony, które nie są znane niemieckiemu prawu karnemu. Można je jednak potraktować jako rodzaj definicji, gdyż ich nazwy stanowią eksplikację znaczenia (3-8 oraz 11). Być może dlatego niektóre środki karne nie zostały uwzględnione w słowniku Aliny i Agnieszki Kilian.

Przeanalizujmy teraz poszczególne propozycje ekwiwalentów przekładowych nazw środków karnych 3-7 i 11. Oceniając ekwiwalenty zawarte w 3 wierszu tabeli, można stwierdzić, iż pod względem stylistycznym ekwiwalent słownikowy jest lepszym rozwiązaniem, gdyż odpowiada stosowanemu w języku prawa stylowi nominalnemu i ma bardziej skondensowaną formę. Pod względem semantycznym jedyne zastrzeżenie budzi sformułowanie użyte w ekwiwalencie słownikowym, a mianowicie Bekleidung bestimmter Ämter, gdzie Ämter (urzędy) ma znaczenie zawężające. W doktrynie prezentowany jest pogląd, że wyrażenie stanowisko ,interpretuje się jako pełnioną funkcję lub pozycję zajmowaną przez obywatela w systemie i hierarchii instytucji państwowych i społecznych, a także prywatnych" (Daniluk 2011, 554). Dlatego też Ämter należałoby zastąpić wyrazem Posten. Warto zauważyć, że w przekładzie autorki słownika wykorzystały termin ustawowy zawarty w $§ 35$ niemieckiej ustawy o działalności gospodarczej (Gewerbeordnung), a mianowicie Gewerbeuntersagung.

Podobna sytuacja ma miejsce w przypadku ekwiwalentów dla środka karnego w wierszu 11. Pozytywnie należy ocenić ekwiwalent słownikowy, który w przeciwieństwie do ekwiwalentu przekładowego, nie jest dosłowną kalką polskiego terminu, lecz uwzględnia treść pojęcia kryjącego się za terminem krzywda. Pojęcie to odnosi się bowiem ,do uszczerbku o charakterze niemajątkowym (np. cierpienia fizyczne lub psychiczne)" (Daniluk 2011, 245-246). Z uwagi na to, że w słowniku nazwa tego środka karnego jest podzielona na dwie części, to w kontekście przekładu kodeksu karnego pełny ekwiwalent przekładowy mógłby brzmieć: Pflicht zum Schadensersatz und zur Wiedergutmachung eines Nichtvermögensschadens.

Wiersz 5 tabeli pokazuje, że zarówno ekwiwalent słownikowy, jak i przekładowy jest niepełny i ten ostatni ma formę konstrukcji bezokolicznikowej, która co prawda nie odpowiada konwencji stylu języka prawnego, lecz jest przejrzysta i zrozumiała. Jako pełne rozwiązanie translacyjne $\mathrm{w}$ formie nominalnej można by zaproponować następujący ekwiwalent: Pflicht zum Fernbleiben von bestimmten Kreisen oder Orten, Kontakt- und Näherungsverbot zu bestimmten Personen, Verbot des Verlassens eines bestimmten Aufnthaltsortes ohne Erlaubnis des Gerichts.

Słownik Aliny i Agnieszki Kilian nie notuje nazw środków karnych 4, 6 i 7, natomiast ekwiwalenty przekładowe są różne pod względem formalnym: nazwa środka karnego w wierszu 4 ma formę konstrukcji bezokolicznikowej, a pozostałe dwa formę nominalną. Ekwiwalent nominalny dla środka karnego 4 mógłby mieć następującą postać: Verbot einer mit Erziehung, Behandlung, Bildung oder Betreueung Minderjähriger verbundenen Tätigkeit. 
Środek karny w pozycji 8, wprowadzony do kodeksu karnego z mocy ustawy z 10.06.2010 r. o zmianie ustawy o przeciwdziałaniu przemocy $\mathrm{w}$ rodzinie oraz niektórych innych ustaw (por. Daniluk 2011, 213), nie został uwzględniony ani w słowniku, ani w przekładzie. Dziwi zwłaszcza jego brak w thumaczeniu kodeksu karnego, gdyż przekład ten ukazał się w 2012 r. i jako datę stanu prawnego podano czerwiec 2012 r. Ekwiwalentem przekładowym mogłoby być następujące sformułowanie: Anordnung des zusammen mit dem Verletzten bewohnten Wohnraumes.

Niemieckie prawo karne nie zna także sankcji karnych w postaci nawiązki, świadczenia pieniężnego oraz degradacji (w przypadku żołnierzy). Nawiązka polega na obowiązku zapłacenia pewnej kwoty na określony cel (por. Hołyst 2005, 478), a świadczenie pieniężne na obowiązku zapłaty wskazanej kwoty pieniężnej na rzecz określonego beneficjenta, innego jednak niż pokrzywdzony (por. Daniluk 2011, 472). Ekwiwalent dla świadczenia pieniężnego zaproponowany zarówno w słowniku, jak i w przekładzie jest terminem niemieckiego prawa socjalnego, oznaczającym świadczenie w formie wypłaty pieniędzy (por Alpmann-Pieper et al. 2010, 492). Pod względem semantycznym ekwiwalent ten jest więc właściwy, choć należy zaznaczyć, że ma on znaczenie szersze. Ekwiwalenty dla nawiązki to ekwiwalenty ograniczające o węższym znaczeniu: zarówno Bußzahlung (prawo postępowania karnego), jak i Geldauflage (prawo karne nieletnich) oznaczają zapłatę określonej kwoty na rzecz instytucji pożytku publicznego. Oba są jednak zrozumiałe dla odbiorcy i akceptowalne. Inna możliwość to utworzenie terminu opisowego: Zahlung eines Geldbetrags für einen bestimmten Zweck. W przypadku degradacji, która zgodnie z art. 327 k.k. obejmuje utratę posiadanego stopnia wojskowego i powrót do stopnia szeregowego, za właściwe rozwiązanie translacyjne należy uznać wybór wyrażenia języka ogólnego, a mianowicie Degradierung.

Jeśli chodzi o nazwy środków karnych $2,9,10,14$ i 15, to w prawie niemieckim można dla nich znaleźć ekwiwalenty funkcjonalne. Dla środka 2 to Verlust der Amtsfähigkeit, der Wählbarkeit und des Stimmrechts lub Aberkennung von Rechten und Fähigkeiten (por. Creifelds 2014, 2). W tym przypadku tłumacz zdecydował się jednak na kalkę językową, która nie jest dobrym rozwiązaniem, gdyż nawiązuje do pojęcia subjektive öffentliche Rechte, które oznacza prawo do żądania od państwa lub innego podmiotu dokonania lub zaniechania określonej czynności (por. Creifelds 2014, 1230). Autorki słownika wybrały ekwiwalent historyczny, gdyż pojęcie Verlust der bürgerlichen Ehrenrechte zostało zniesione w 1970 r. i zastąpione pojęciem węższym Aberkennung von Rechten und Fähigkeiten (por. Creifelds 2014, 331). Wydaje się jednak, że w tym kontekście zaproponowany ekwiwalent słownikowy jest akceptowalny, gdyż dla odbiorcy, który jest karnistą i zna historię prawa karnego, jest on przejrzysty znaczeniowo.

W przypadku środka karnego 14 ani w słowniku ani w przekładzie nie skorzystano z ekwiwalentu funkcjonalnego zawartego $\mathrm{m}$. in. w $\S 165 \mathrm{StGB}$, a mianowicie Bekanntgabe der Verurteilung, lecz zdecydowano się na kalkę językową, która jest jednak przejrzysta znaczeniowo i można ją ocenić jako rozwiązanie poprawne. 
Ekwiwalenty funkcjonalne zarówno autorki słownika, jak i tłumacze wykorzystali dla nazw środków karnych zawartych w wierszu 9 i 10 tabeli: Fahrverbot oraz Einziehung i Verfall. W odniesieniu do dwóch ostatnich terminów należy zauważyć, że Einziehung dotyczy przepadku przedmiotów i praw, a Verfall przepadku korzyści majątkowej (por. Alpmann-Pieper 2010, 364, 1244). Z uwagi na to, że w polskim prawie karnym przepadek dotyczy zarówno przedmiotów, jak i korzyści majątkowych (por. Daniluk 2011,364), to wydaje się, że odpowiednim rozwiązaniem translacyjnym byłoby zastosowanie techniki 7, czyli podanie dwóch terminów na oznaczenie jednego, a więc Einziehung und Verfall.

Dla środka karnego 15 ekwiwalent funkcjonalny można znaleźć w $§ 43$ niemieckiej ustawy o statusie prawnym żołnierzy (Gesetz über die Rechtsstellung der Soldaten): Entfernung aus dem Dienstverhältnis. Ekwiwalent ten jest lepszym rozwiązaniem niż zaproponowana w przekładzie kalka językowa, tym bardziej że wyrażenie Berufsdienst des Militärs jest znaczeniowo nieprzejrzyste.

\section{Podsumowanie}

Przeprowadzona w niniejszym artykule analiza słownikowych i przekładowych ekwiwalentów nazw kar i środków karnych przewidzianych w polskim kodeksie karnym potwierdziła, że kluczowy etap procesu tłumaczenia tekstów prawnych stanowi wnikliwe badanie treści pojęć prawnych przede wszystkim na podstawie jednojęzycznych słowników, leksykonów i komentarzy prawniczych. Badanie wykazało także, że w przekładzie tego typu tekstów pomocą mogą służyć dwujęzyczne słowniki specjalistyczne oraz dostępne na rynku przekłady tekstów prawnych (w przeprowadzonym tutaj badaniu przekład polskiego kodeksu karnego) oraz że ze źródeł tych należy jednak korzystać $\mathrm{z}$ dużą ostrożnością. Stwierdzenie to znajduje potwierdzenie w ogólnie przyjętym poglądzie, że ekwiwalenty słownikowe stanowią zwykle jedynie przybliżone odpowiedniki semantyczne, a nie gotowe rozwiązania translacyjne i że dobór ekwiwalentów przekładowych zależy od kontekstu sytuacyjnego. Przeprowadzona konfrontacja ekwiwalentów słownikowych i przekładowych wykazała tymczasem, że niekiedy słownikowe propozycje rozwiązań translacyjnych są bardziej odpowiednie niż zastosowane w tekście ekwiwalenty przekładowe. Pozwala to stwierdzić, że w przypadku przekładu terminów prawnych istotną rolę odgrywa nie tylko sytuacja komunikacyjna, lecz także wiedza specjalistyczna i znajomość konwencji językowych obowiązujących w kulturze docelowego języka prawnego. Ich najlepszym i godnym zaufania źródłem są natomiast teksty paralelne, co potwierdziły także wyniki niniejszego badania. 


\section{Bibliografia}

Alpmann-Pieper, Annegerd, Josef A. Alpmann, Rolf Krüger, i Horst Wüstenbecker, red. 2010 Alpmann Brockhaus Studienlexikon Recht. München: C. H. Beck.

Bojarski, Tadeusz. 2008. Polskie prawo karne. Zarys części ogólnej. Warszawa: LexisNexis.

Chudzik, Joanna, Michał Jakowczyk, Kaja Kowalski, Andreas Krajewski, i Kamila Mtthies, tłum. 2012. Strafgesetzbuch und Übertretungsgesetzbuch. Kodeks karny i kodeks wykroczeń. Warszawa: C.H. Beck.

Cieślak, Wojciech. 2010. Prawo karne. Zarys instytucji i naczelne zasady. Warszawa: Wolters Kluwer.

Ciszewski, Jan. 2008. Obrót prawny z zagranica w sprawach cywilnych i karnych. Warszawa: LexisNexis.

Creifelds, Carl. 2014. Rechtswörterbuch. München: C. H. Beck.

Daniluk, Paweł, red. 2011. Leksykon prawa karnego - część ogólna. 100 podstawowych pojęć. Warszawa: C. H. Beck.

Dybiec-Gajer, Joanna. 2013. Specyfikacja jako instrument kontekstualizacji aktu tłumaczeniowego - między teorią a praktyką dydaktyki przekładu. Rocznik Przekładoznawczy nr 8, ss. 107-121.

Gabriel-Węglowski, Michał. 2011. Koncepcja usprawnienia instytucjonalnego prokuratury w zwalczaniu przestępczości zorganizowanej. Prokuratura i Prawo nr 4, ss. 73102.

Groot, Gerard-René de. 1999. Das Übersetzen juristischer Terminologie. W Recht und Übersetzen, red. Gerard-René de Groot, Reiner Schulze, ss. 11-46. BadenBaden: Nomos Verlagsgesellschaft.

Hołyst, Brunon, red. 2005. Wielka encyklopedia prawa. Warszawa: Wydawnictwo Prawo i Praktyka Gospodarcza.

Jopek-Bosiacka, Anna. 2006. Przekład prawny i sądowy. Warszawa: Wydawnictwo Naukowe PWN.

Kapuściński, Ryszard. 2008. Rwacy nurt historii - zapiski o XX i XXI wieku. Kraków: Wydawnictwo Znak.

Kierzkowska, Danuta. 2002. Tłumaczenie prawnicze. Warszawa: Wydawnictwo TEPIS.

Kierzkowska, Danuta. 2010. Odbiorcy thumaczenia tekstu pragmatycznego, czyli teoria w praktyce. W Translatoryka - Koncepcje - Modele - Analizy, red. Sambor Grucza, Adam Marchwicki, Monika Płużyczka, ss. 262-268. Warszawa: Wydawnictwo Uniwersytetu Warszawskiego.

Kilian, Alina, i Agnieszka Kilian. 2014a. Słownik języka prawniczego i ekonomicznego polsko-niemiecki. Warszawa: Wolters Kluwer.

Kilian, Alina, i Agnieszka Kilian. 2014b. Słownik języka prawniczego i ekonomicznego niemiecko-polski. Warszawa: Wolters Kluwer.

Köbler, Gerhard. 2007. Juristisches Wörterbuch. Für Studium und Ausbildung. München: Franz Vahlen.

Kubacki, Artur. 2014. Pluricentryzm w niemieckim języku standardowym i specjalistycznym. Legilingwistyka Porównawcza t. 17, ss. 163-181.

Marek, Andrzej. 1999. Komentarz do kodeksu karnego. Część ogólna. Warszawa: Wydawnictwo Prawnicze Sp. z o.o. 
Marek, Andrzej. 2005. Prawo karne. Warszawa: C. H. Beck.

Matulewska, Aleksandra. 2005. Własność i zobowiązania w aspekcie translatorycznym polsko-angielskim i angielsko-polskim. Investigationes Linguisticae t. 12, ss. 62-76.

Pawela, Stanisław. 2007. Prawo karne wykonawcze. Zarys wykładu. Warszawa: Wolters Kluwer.

Steinborn, Sławomir. 2011. Prawomocność części orzeczenia w procesie karnym. Warszawa: Wolters Kluwer.

Weisflog, Walter E. 1996. Rechtsvergleichung und juristische Übersetzung. Eine interdisziplinäre Studie. Zürich: Schulthess Polygraphischer Verlag.

\section{Źródla internetowe}

Europejska konwencja o pomocy prawnej w sprawach karnych z dnia 20 kwietnia 1959 r. http://isap.sejm.gov.pl/Download?id=WDU19990760854\&type=2\&nr=1 (data dostępu: 02.06.2014)

Gesetz über die Rechtsstellung der Soldaten. http://www.gesetze-im-internet.de/bundesrecht/ sg/gesamt.pdf (data dostępu: 09.06.2014)

Gewerbeordnung. http://www.gesetze-im-internet.de/bundesrecht/gewo/gesamt.pdf (data dostępu: 09.06.2014)

Strafgesetzbuch in der Fassung der Bekanntmachung vom 13. November 1998. http://www.gesetze-im-internet.de/bundesrecht/stgb/gesamt.pdf (data dostępu: 30.05.2014)

Ustawa z dnia 6 czerwca 1997 r. - Kodeks karny. http://isap.sejm.gov.pl/Download;jsessionid= D9C3BC66C700683605A8A52AB38BB93D?id=WDU19970880553\&type=3

(data dostępu: 30.05.2014)

Walka z przestępczością zorganizowaną. http://europa.eu/legislation_summaries/justice_freedom_security/fight against_organised_crime/index_pl.htm (data dostępu: 02.06.2014) 
